\title{
Positives, Potential, and Preparation: Pre-service Special Educators' Knowledge About Teaching Reading to Children with Down Syndrome
}

\author{
Leila A. Ricci and Anna Osipova \\ California State University, Los Angeles
}

\begin{abstract}
In this era of reading as a priority, research has indicated that children with Down syndrome (DS) can indeed learn to read, attaining functional levels of literacy and beyond. Families of children with DS are also increasingly advocating for reading instruction for their children. However, few studies have examined what beginning educators know about reading and DS. This study explored the knowledge and perceptions of pre-service special educators about the reading needs and abilities of children with DS. Participants were 225 university students, enrolled in special education teaching credential programs in two southern California universities, who completed a survey designed to assess their knowledge of teaching reading to children with DS, as well as to describe their approach to reading instruction with these students. Results showed promising knowledge on the part of these future teachers, but also highlight the importance of adequate teacher preparation in teaching reading to children with $D S$.
\end{abstract}

In this current era, reading is more than ever a priority for all children, propelling them to later college and career readiness. From legislation such as No Child Left Behind (NCLB, 2001) to the Common Core State Standards Initiative (2014), U.S. policymakers and educators alike have focused on making every child a successful reader as a gateway to full educational access (American Federation of Teachers, 2008). Parents and advocacy groups have called for the inclusion of children with Down syndrome (DS) in this effort as well, especially as research has indicated that individuals with DS can attain functional levels of literacy, that they can develop reading skills above that which is 
expected for their mental age, and that the process of reading can further their cognitive and language abilities (Buckley, 1995; Byrne, Buckley, MacDonald, \& Bird, 1995; Byrne, MacDonald, \& Buckley, 2002; Cologon, Cupples, \& Wyver, 2011; Lemons \& Fuchs, 2010; Lemons, Mrachko, Kostewicz, \& Paterra, 2012; Ricci, 2011a, 2011b). In the context of the current push for inclusion of all children with disabilities, educators also recognize the importance of personalization in reading instruction, identifying students' specific strengths and needs and providing appropriate individualized intervention as needed (Lemons et al., 2017; Lemons, Kearns, \& Davidson, 2014). An area that remains unexplored is how much teachers know about the reading potential and needs of children with DS. The present study examined pre-service special educators' perceptions about the reading achievement and needs of children with DS.

As DS is the most common genetic cause of intellectual disability (Burgoyne et al., 2012), researchers have studied the behavioural phenotype of this population, which in turn influences reading skills in these children. For instance, children with DS often show a weakness in expressive language and a relative strength in visual memory (Fowler, 1990; Hodapp, Evans, \& Gray, 1999; Hodapp \& Ricci, 2002; Kumin, 1994; Leddy, 1999). Some studies have shown that individuals with DS tend to perform better on tasks requiring visual versus auditory memory (Daunhauer \& Fidler, 2011; Frenkel \& Bourdin, 2009; Lemons et al., 2017; Vicari, Marotta, \& Carlesimo, 2004). Although there is a wide range of reading achievement among these individuals, as many as half of children and adolescents with DS were able to read at least 50 words (Buckley, Bird, \& Byrne, 1996; Buckley \& Sacks, 1987). Some $60 \%$ to $70 \%$ of individuals with DS in Australia and the United Kingdom have attained functional levels of literacy (Buckley, 2001). Some children with DS can read at levels that are not only comparable to the reading abilities of typically developing children, but are also more advanced than their own cognitive abilities (Byrne et al., 1995; Byrne et al., 2002).

Some researchers have found that the very act of reading helps improve the speech and language skills of children with DS (Buckley, 2001; Buckley \& Johnson-Glenberg, 2008; Laws, Buckley, Bird, MacDonald, \& Broadley, 1995), thus recommending early sight-word instruction to very young children to promote their emergent literacy and provide a context for later instruction in phonemic awareness and decoding. Children with DS have also been found to improve in their reading skills as a result of targeted interventions (Burgoyne et al., 2012; Cologon et al., 2011; Colozzo, McKeil, Petersen, \& Szabo, 2016; van Bysterveldt \& Gillon, 2014). Researchers using commercially available, evidence-based reading interventions with children with DS aged 5 to 13 years found improvements in their reading of both phonetically regular and high frequency words (Lemons et al., 2012).

Children with DS benefit from comprehensive reading instruction targeting phonemic awareness, phonics, decoding, sight-word instruction, vocabulary, fluency, and reading comprehension, with emphasis on additional review, practice, and generalization (Allor, Mathes, Roberts, Cheatham, \& Al Otaiba, 2014; Allor, Mathes, Roberts, Cheatham, \& Champlin, 2010; Cologon, 2013; Lemons et al., 2012; Lemons et al., 2017; Næss, MelbyLervåg, Hulme, \& Lyster, 2012). Furthermore, research has shown that children with DS learn best when words are imageable, are associated with familiar objects, or when contextual support is given (Beeghly \& Cicchetti, 1997; Chapman \& Hesketh, 2000). The 
relative strength in visual memory associated with DS suggests that early reading instruction would be more effective by increasing visual support in order to reduce the load on verbal working memory (Lemons et al., 2017). Although phonemic awareness and decoding are important for comprehensive reading instruction, it is appropriate for children to learn meaningful whole words in the very early stages of their literacy development (Whitehurst \& Lonigan, 1998). Reading environmental print is an example of emergent literacy (Sulzby \& Teale, 1991). Teaching sound awareness or letter identification early on without context is not as meaningful, particularly to children with DS who often struggle with vocabulary and concept development due to their intellectual disability, and benefit from semantic representations onto which the phonological code can be mapped.

Parents of children with DS have long been advocates for reading instruction for their children, advocating for appropriate speech and reading interventions (Fidler, Hodapp, \& Dykens, 2002; Fidler, Lawson, \& Hodapp, 2003). Parents do seem to provide rich home literacy environments for these children, with the most frequent literacy activity being shared story reading (Fitzgerald, Roberts, Pierce, \& Schuele, 1995). Families of children with DS report having 50 or more children's books in their homes and reading to their children for 10 to 30 minutes per day (Al Otaiba, Lewis, \& Whalon, 2009). In a study of 50 children with DS aged 3 to 13 years, parents described their children's positive attitude toward reading, stated their reading-related goals for their children, defined their children's relative strengths in reading, and shared strategies used in the home to promote literacy in this population. Parents thus are attuned to and have high expectations for their children's reading achievement, and thereby would benefit from partnerships with informed educators capable of teaching reading to children with DS (Ricci, 2011a; Ricci \& Osipova, 2012). In a study of the educationally related knowledge of parents of children with intellectual disabilities, $23.8 \%$ of parents reported that their children with DS received instruction in reading in their schools (Fidler et al., 2002). In addition, $60 \%$ of the parents in the study wanted more reading instruction for their children with DS. In a similar study, researchers found that parents of children with DS had a range of responses regarding reading, with some indicating an emphasis on overall reading instruction and others emphasizing specific skills and programs (Fidler et al., 2003).

In light of these documented home practices and hopes of families of children with DS, it is crucial to further investigate teachers' views on the reading development and needs of these children. The current study extends earlier research by exploring the knowledge and perceptions of pre-service special educators about the reading needs and achievement of children with DS, and whether these future teachers express competence and accuracy in their approach to reading instruction for these children.

\section{Method}

\section{Participants}

Participants consisted of 225 university students enrolled in special education teaching credential programs in two large, public southern California universities. The students were 54 males and 171 females, with an average age of 31.6 years. Among these, 23\% were Caucasian, 54\% Hispanic, 20\% Asian American, 2\% African American, and 1\% identified themselves as being of mixed ethnicity. Students were enrolled in teacher credential 
programs leading to licensure in teaching students with mild-moderate disabilities $(81 \%)$ or moderate-severe disabilities (19\%). Data was collected from the students in reading courses of their special education teacher licensure programs at their respective universities. One of us (Ricci) visited these courses to invite students to participate in the study. After agreeing to participate in the study, the pre-service special educators were given a survey to complete either in class or at home. Anonymity from course professors was maintained, as students returned the surveys directly to us at a later time, in person or by mail.

\section{Measure}

Pre-service special educators completed a survey designed to assess their knowledge and perceptions of teaching reading to children with DS, as well as to describe their approach to reading instruction with these students. The 18-item survey based on findings of the emerging research on reading and children with DS measured whether these teachers were aware of such findings and could apply it to their teaching. Survey items consisted of items such as "Children with Down syndrome can benefit from reading instruction as early as two years old," "The reading achievement of children with Down syndrome can be the same as or greater than what is expected for their cognitive ability," and "By the time individuals with Down syndrome are teenagers and young adults, reading instruction provides little benefit for them" (reverse scored). Results for the 18 items added together yield possible total scores ranging from 0 to $72(1=$ strongly disagree; 4 = strongly agree; a score of 0 was assigned to not sure responses). Higher scores indicated more competence in teaching reading to children with DS. Cronbach's alpha was .82 for the 225 participants completing this survey. See Results for rest of the survey items. In addition, the pre-service teachers were asked to respond to an openended question asking how they would approach reading instruction for children with DS, including any specific reading strategies for teaching them how to read.

\section{Data Analysis Procedures}

The 18 items of the survey were combined (after reverse scoring of appropriate items) to create a total score for each participant. The quantitative data from the survey was analyzed using SPSS. Descriptive statistics using frequency counts and percentages of responses were examined to determine the trends in the data. Qualitative responses were coded using the grounded theory approach (Glaser \& Strauss, 1967).

Open codes. Initially, the pre-service teachers' responses to the open-ended question were coded using open codes. Every sentence or thematically organized cluster of sentences that contained a complete thought was given a code. We independently identified 36 codes, as we coded $30 \%$ of the data. We first reached $67 \%$ agreement in our initial codes, and then discussed and resolved differences until agreement on initial codes reached $90 \%$.

Themes. During the second step of analysis, the codes were analyzed for emerging themes. The 36 initial open codes were collapsed into five central themes. We then independently coded $30 \%$ of the data for these emerging themes, reaching $85 \%$ inter-rater reliability in this process. After discussing and resolving any differences, the rest of the participant data was then coded according to the themes. We also coded each participant's 
overall response for accuracy (How accurate overall is the response in terms of being appropriate reading instruction for children with DS?); depth (How rich is the response given? Depth versus surface level response); and growth mindset (How competent do preservice special educators seem in terms of providing appropriate reading instruction, and do they demonstrate belief in the capacity of child with DS to read?). For coding of accuracy of responses, we used recommendations for effective reading instruction posited in the United States by the National Reading Panel (2000) and by the work of Connor, Alberto, Compton, and O'Connor (2014). The participants' responses were rated on a scale of 0 to $4(0=$ no evidence; $4=$ high evidence $)$. To ensure the validity of this study, we adopted the following practices, as recommended for sound analysis of qualitative data (Brantlinger, Jimenez, Klingner, Pugach, \& Richardson, 2005). First, we met frequently during the data coding process in order to ensure credibility of qualitative coding. The coding system described above was developed and finalized based on these discussions. We held discussions throughout the open coding stage and during the stage when the five key themes and overall evaluations were identified and coded.

\section{Results}

Out of the 225 pre-service special educators participating in this study, 153 reported having experience with or knowing a child with DS, while 72 reported no such experience. There was a significant difference in mean total scores between those preservice teachers with prior experience and those without prior experience with children with DS (prior experience, $M=37.79$; no experience, $M=29.93 ; t(1,223)=4.654, p<$ .000). Table 1 shows the mean total scores of the pre-service special educators based on the type of prior experience they had with children with DS, with the highest scores for those who reported prior professional experience with these children (e.g., serving as a paraprofessional). There were no differences in total scores based on participants' gender, age, or ethnicity. However, there were differences in mean total scores between preservice teachers enrolled in the mild-moderate disabilities credential program (MM) and those enrolled in the moderate-severe disabilities credential programs (MS), with the latter group scoring higher than the former (MM, $M=35.13$ (12.12); $\mathrm{MS}, M=42.72$ $(8.06) ; t(156)=-7.59, p<.01)$.

Table 1.

Mean Total Scores of Participants Based on Type of Prior Experience

\begin{tabular}{lrr}
\hline Type of Experience with Children with DS & \multicolumn{2}{c}{$\begin{array}{c}\text { Mean Total Score } \\
\text { (SD) }\end{array}$} \\
\hline No prior experience $(n=72)$ & 30.31 & $(12.77)$ \\
Prior personal experience with a child with DS $(n=63)$ & 33.52 & $(12.82)$ \\
Prior professional experience with a child with DS $(n=90)$ & 40.45 & $(9.52)$ \\
\hline
\end{tabular}

The items on which moderate-severe disabilities candidates scored higher were the following: "Reading instruction at an early age can improve the working memory and language skills of children with Down syndrome" (MM, $M=2.68$ (1.33); MS, $M=3.33$ $(.97) ; t(156)=-.66, p<.05)$; "Children with Down syndrome benefit most from 'whole- 
word' instruction in the early stage of literacy development" (MM, $M=1.49$ (1.47); MS, $M=2.56(1.10) ; t(156)=-1.07, p<.05)$; "The expressive language abilities of children with Down syndrome must be developed before they can benefit from instruction in reading" (reverse scored; MM, $M=1.57$ (1.32); MS, $M=2.56$ (.86); $t(156)=-.98$, $p<.01)$; and "I feel competent to teach children with Down syndrome to read" (MM, $M$ $=2.12$ (1.27); $\mathrm{MS}, M=2.72(1.13) ; t(156)=-.98, p<.01)$. Because many fewer preservice teachers enrolled in the moderate-severe disabilities program than enrolled in the mild-moderate program, the rest of the analyses were conducted on the entire sample of 225 pre-service special educators.

The majority of these pre-service special educators $(87 \%)$ reported that they believe children with DS can be taught to read. A majority of participants (84\%) reported they believe that most children with DS will benefit from reading instruction, and that reading instruction at an early age can improve the working memory and language of children with DS (83\%). Many reported that they believe children with DS can benefit from reading instruction as early as two years old (65\%), and that the reading achievement of children with DS can be the same or greater than what is expected for their language ability (63\%) and cognitive ability (62\%). Slightly more than half reported that they feel competent in teaching children with DS to read (53\%). See Table 2 for frequency of participants' responses to each of the survey questions.

Table 2.

Perceptions of Pre-service Special Educators about Reading and DS

\begin{tabular}{|c|c|c|c|c|c|c|}
\hline & Questions & $\begin{array}{l}\text { Strongly } \\
\text { Agree }\end{array}$ & Agree & Disagree & $\begin{array}{l}\text { Strongly } \\
\text { Disagree }\end{array}$ & $\begin{array}{l}\text { Not } \\
\text { Sure }\end{array}$ \\
\hline 1. & $\begin{array}{l}\text { I believe that children with Down syndrome } \\
\text { can be taught to read. }\end{array}$ & $\begin{array}{c}101 \\
(45 \%)\end{array}$ & $\begin{array}{c}97 \\
(43 \%)\end{array}$ & $\begin{array}{c}1 \\
(<1 \%)\end{array}$ & $\begin{array}{c}7 \\
(3 \%)\end{array}$ & $\begin{array}{c}19 \\
(8 \%)\end{array}$ \\
\hline 2. & $\begin{array}{l}\text { Children with Down syndrome are generally } \\
\text { better visual learners than auditory learners. }\end{array}$ & $\begin{array}{c}39 \\
(17 \%)\end{array}$ & $\begin{array}{c}71 \\
(32 \%)\end{array}$ & $\begin{array}{c}14 \\
(6 \%)\end{array}$ & $\begin{array}{c}1 \\
(<1 \%)\end{array}$ & $\begin{array}{c}100 \\
(44 \%)\end{array}$ \\
\hline 3. & $\begin{array}{l}\text { The expressive language abilities of children } \\
\text { with Down syndrome must be developed } \\
\text { before they can benefit from instruction in } \\
\text { reading (reverse scored). }\end{array}$ & $\begin{array}{c}24 \\
(11 \%)\end{array}$ & $\begin{array}{c}51 \\
(23 \%)\end{array}$ & $\begin{array}{c}74 \\
(33 \%)\end{array}$ & $\begin{array}{c}12 \\
(5 \%)\end{array}$ & $\begin{array}{c}64 \\
(28 \%)\end{array}$ \\
\hline 4. & $\begin{array}{l}\text { Most children with Down syndrome will benefit } \\
\text { from reading instruction. }\end{array}$ & $\begin{array}{c}99 \\
(44 \%)\end{array}$ & $\begin{array}{c}90 \\
(40 \%)\end{array}$ & $\begin{array}{c}10 \\
(4 \%)\end{array}$ & $\begin{array}{c}7 \\
(3 \%)\end{array}$ & $\begin{array}{c}19 \\
(8 \%)\end{array}$ \\
\hline 5. & $\begin{array}{l}\text { Children with Down syndrome can achieve } \\
\text { reading skills that are the same as expected } \\
\text { for their age level. }\end{array}$ & $\begin{array}{c}18 \\
(8 \%)\end{array}$ & $\begin{array}{c}61 \\
(27 \%)\end{array}$ & $\begin{array}{c}74 \\
(33 \%)\end{array}$ & $\begin{array}{c}12 \\
(5 \%)\end{array}$ & $\begin{array}{c}60 \\
(27 \%)\end{array}$ \\
\hline 6. & $\begin{array}{l}\text { I feel competent to teach children with Down } \\
\text { syndrome to read. }\end{array}$ & $\begin{array}{c}22 \\
(10 \%)\end{array}$ & $\begin{array}{c}96 \\
(43 \%)\end{array}$ & $\begin{array}{c}52 \\
(23 \%)\end{array}$ & $\begin{array}{c}15 \\
(6 \%)\end{array}$ & $\begin{array}{c}40 \\
(18 \%)\end{array}$ \\
\hline 7. & $\begin{array}{l}\text { Children with Down syndrome can benefit from } \\
\text { reading instruction as early as two years old. }\end{array}$ & $\begin{array}{c}42 \\
(19 \%)\end{array}$ & $\begin{array}{c}103 \\
(46 \%)\end{array}$ & $\begin{array}{c}16 \\
(7 \%)\end{array}$ & $\begin{array}{c}2 \\
(1 \%)\end{array}$ & $\begin{array}{c}62 \\
(27 \%)\end{array}$ \\
\hline 8. & $\begin{array}{l}\text { Children with Down syndrome may be able to } \\
\text { read as well as or better than typical slower } \\
\text { readers. }\end{array}$ & $\begin{array}{c}29 \\
(13 \%)\end{array}$ & $\begin{array}{c}99 \\
(44 \%)\end{array}$ & $\begin{array}{c}23 \\
(10 \%)\end{array}$ & $\begin{array}{c}1 \\
(<1 \%)\end{array}$ & $\begin{array}{c}73 \\
(32 \%)\end{array}$ \\
\hline & $\begin{array}{l}\text { The reading achievement of children with } \\
\text { Down syndrome can be the same as or }\end{array}$ & $\begin{array}{c}20 \\
(9 \%)\end{array}$ & $\begin{array}{c}120 \\
(53 \%)\end{array}$ & $\begin{array}{c}29 \\
(13 \%)\end{array}$ & $\begin{array}{c}1 \\
(<1 \%)\end{array}$ & $\begin{array}{c}55 \\
(24 \%)\end{array}$ \\
\hline
\end{tabular}
greater than what is expected for their cognitive ability.

Continued... 


\begin{tabular}{|c|c|c|c|c|c|}
\hline Questions & $\begin{array}{c}\text { Strongly } \\
\text { Agree }\end{array}$ & Agree & Disagree & $\begin{array}{l}\text { Strongly } \\
\text { Disagree }\end{array}$ & $\begin{array}{l}\text { Not } \\
\text { Sure }\end{array}$ \\
\hline $\begin{array}{l}\text { 10. Children with Down syndrome benefit most } \\
\text { from solely phonics instruction in the early } \\
\text { stage of literacy development (reverse scored) }\end{array}$ & $\begin{array}{c}33 \\
(15 \%)\end{array}$ & $\begin{array}{c}94 \\
(42 \%)\end{array}$ & $\begin{array}{c}15 \\
(6 \%)\end{array}$ & $\begin{array}{c}2 \\
(1 \%)\end{array}$ & $\begin{array}{c}81 \\
(36 \%)\end{array}$ \\
\hline $\begin{array}{l}\text { 11. Children with Down syndrome often begin } \\
\text { using alphabetic strategies at the reading age } \\
\text { of seven years. }\end{array}$ & $\begin{array}{c}4 \\
(2 \%)\end{array}$ & $\begin{array}{c}41 \\
(18 \%)\end{array}$ & $\begin{array}{c}16 \\
(7 \%)\end{array}$ & $\begin{array}{c}2 \\
(1 \%)\end{array}$ & $\begin{array}{c}162 \\
(72 \%)\end{array}$ \\
\hline $\begin{array}{l}\text { 12. Reading instruction at an early age can } \\
\text { improve the working memory and language } \\
\text { skills of children with Down syndrome. }\end{array}$ & $\begin{array}{c}51 \\
(23 \%)\end{array}$ & $\begin{array}{c}135 \\
(60 \%)\end{array}$ & $\begin{array}{c}2 \\
(1 \%)\end{array}$ & $\begin{array}{c}1 \\
(<1 \%)\end{array}$ & $\begin{array}{c}36 \\
(16 \%)\end{array}$ \\
\hline $\begin{array}{l}\text { 13. The reading achievement of children with } \\
\text { Down syndrome can be the same as or } \\
\text { greater than what is expected for their } \\
\text { language ability. }\end{array}$ & $\begin{array}{c}21 \\
(9 \%)\end{array}$ & $\begin{array}{c}121 \\
(54 \%)\end{array}$ & $\begin{array}{c}21 \\
(9 \%)\end{array}$ & $\begin{array}{c}1 \\
(<1 \%)\end{array}$ & $\begin{array}{c}61 \\
(27 \%)\end{array}$ \\
\hline $\begin{array}{l}\text { 14. When children with Down syndrome read aloud, } \\
\text { their speech can become more intelligible. }\end{array}$ & $\begin{array}{c}11 \\
(5 \%)\end{array}$ & $\begin{array}{c}92 \\
(41 \%)\end{array}$ & $\begin{array}{c}1 \\
(<1 \%)\end{array}$ & $\begin{array}{c}25 \\
(11 \%)\end{array}$ & $\begin{array}{c}96 \\
(43 \%)\end{array}$ \\
\hline $\begin{array}{l}\text { 15. Individuals with Down syndrome can have } \\
\text { independent reading ability if they achieve a } \\
\text { reading level equivalent to that of a typical 8- } \\
\text { year-old. }\end{array}$ & $\begin{array}{c}16 \\
(7 \%)\end{array}$ & $\begin{array}{c}82 \\
(36 \%)\end{array}$ & $\begin{array}{c}14 \\
(6 \%)\end{array}$ & $\begin{array}{c}1 \\
(<1 \%)\end{array}$ & $\begin{array}{c}112 \\
(50 \%)\end{array}$ \\
\hline $\begin{array}{l}\text { 16. Children with Down syndrome benefit most } \\
\text { from "whole-word" instruction in the very early } \\
\text { stage of literacy development. }\end{array}$ & $\begin{array}{c}20 \\
(9 \%)\end{array}$ & $\begin{array}{c}69 \\
(30 \%)\end{array}$ & $\begin{array}{c}24 \\
(11 \%)\end{array}$ & $\begin{array}{c}4 \\
(2 \%)\end{array}$ & $\begin{array}{c}108 \\
(48 \%)\end{array}$ \\
\hline $\begin{array}{l}\text { 17. Children with Down syndrome are generally } \\
\text { better auditory learners than visual learners } \\
\text { (reverse scored) }\end{array}$ & $\begin{array}{c}1 \\
(<1 \%)\end{array}$ & $\begin{array}{c}29 \\
(13 \%)\end{array}$ & $\begin{array}{c}63 \\
(28 \%)\end{array}$ & $\begin{array}{c}11 \\
(5 \%)\end{array}$ & $\begin{array}{c}121 \\
(54 \%)\end{array}$ \\
\hline $\begin{array}{l}\text { 18. By the time individuals with Down syndrome } \\
\text { are teenagers and young adults, reading } \\
\text { instruction provides little benefit for them } \\
\text { (reverse scored). }\end{array}$ & $\begin{array}{c}14 \\
(6 \%)\end{array}$ & $\begin{array}{c}63 \\
(28 \%)\end{array}$ & $\begin{array}{c}59 \\
(26 \%)\end{array}$ & $\begin{array}{c}39 \\
(17 \%)\end{array}$ & $\begin{array}{c}50 \\
(22 \%)\end{array}$ \\
\hline
\end{tabular}

Notes: $N=225$ pre-service special education teachers; values are counts of responses followed by percentage of total responses in parentheses.

In analyzing the pre-service special educators' open-ended responses to their approach to reading instruction for children with DS, five key themes emerged: (a) content of reading, (b) pedagogy of reading instruction, (c) connections to the home, (d) unsure but makes recommendation, and (e) no response given. Content of reading refers to participants' description of specific knowledge or skill areas of reading instruction, or the what of reading, such as phonemic awareness, letter-sound correspondence, decoding, vocabulary, fluency, and reading comprehension. Pedagogy of reading instruction refers to the how of reading instruction, or teaching behaviours and approaches to reading instruction. Connections to the home refers to encouraging parental involvement and facilitating a rich home literacy environment. Unsure but makes recommendation refers to replies in which participants stated that they did not know how to approach reading instruction for children with DS, but offered a plan for determining how to do so (e.g., doing research, talking to experts). No response given was assigned when participants did not respond or stated that they did not know what to do. The most frequent theme was pedagogy of reading instruction (53\% of participants) and the least frequent was unsure $(5 \%)$. In all, $9 \%$ of the pre-service special educators mentioned content of reading and 
pedagogy of reading instruction as well as connections to the home. By comparison, 22\% discussed the content and pedagogy of reading, without mention of home connections. See Table 3 for percentages for each theme, as well as examples of participants' responses.

Table 3.

Percentages of Themes and Sample Responses

\begin{tabular}{|c|c|}
\hline $\begin{array}{c}\text { Themes } \\
\text { (\% of Participants) }\end{array}$ & Examples of Participants' Responses \\
\hline $\begin{array}{l}\text { Content of reading } \\
(34 \%)\end{array}$ & $\begin{array}{l}\text { - Teach sight words and environmental print } \\
\text { - Make sure student achieves phonemic awareness } \\
\text { - Teach alphabet/letters-sound correspondence } \\
\text { - Learn systematic phonics } \\
\text { - Letter names and sounds with blending } \\
\text { - Simple CVC words } \\
\text { - Teach decoding and then build their fluency and comprehension } \\
\text { - Vocabulary development } \\
\text { - Reading comprehension }\end{array}$ \\
\hline $\begin{array}{l}\text { Pedagogy of } \\
\text { reading instruction } \\
(53 \%)\end{array}$ & $\begin{array}{l}\text { - Small group or } 1: 1 \text { instruction } \\
\text { - Visuals with hands-on materials } \\
\text { - Instruction tailored to the child's ability, IEP goals, age, grade } \\
\text { - Base instruction on child's assessment, abilities, and weaknesses } \\
\text { - Hands-on experiences to increase comprehension } \\
\text { - Assess first, then match intervention to student's needs } \\
\text { - Ask relevant questions about the reading } \\
\text { - Engage students in creating sentences and stories of their own } \\
\text { - Explicit approach with lots of concrete input, repetition, and visual components } \\
\text { - Have child practise reading with real life things such as recipes } \\
\text { - Use guided reading }\end{array}$ \\
\hline $\begin{array}{l}\text { Connections to the } \\
\text { home } \\
(17 \%)\end{array}$ & $\begin{array}{l}\text { - Establish literature as part of school and home life } \\
\text { - Model love of reading at home } \\
\text { - Have the parent read first and the child re-read later } \\
\text { - Encourage parent to read to child by pointing to words and talking about pictures } \\
\text { - Parent can label objects student uses often at home to associate letters with object } \\
\text { - At home, parents should read to child and provide language-rich environment } \\
\text { - Point or mark the words as the parent reads to the child }\end{array}$ \\
\hline $\begin{array}{l}\text { Unsure but makes } \\
\text { recommendation } \\
(5 \%)\end{array}$ & $\begin{array}{l}\text { - Search for strategies on how to teach students with DS } \\
\text { - I would ask parents what worked in the past with their child } \\
\text { - Research best practices for teaching students with DS } \\
\text { - Research specific sites to gather strategies to help the child } \\
\text { - I would ask colleagues with DS experience }\end{array}$ \\
\hline $\begin{array}{l}\text { No response given } \\
(37 \%)\end{array}$ & $\begin{array}{l}\text { - Lack of experience } \\
\text { - No answer } \\
\text { - No suggestions } \\
\text { - Not sure } \\
\text { - Lack of qualification } \\
\text { - No clue }\end{array}$ \\
\hline
\end{tabular}

Furthermore, nearly half of the pre-service special educators' responses indicated little to some evidence of accuracy, depth, and growth mindset (44\% for accuracy, 47\% 
for depth, and $49 \%$ for growth mindset). Only $11 \%$ of their responses reflected sufficient to high evidence of accuracy, $8 \%$ reflected sufficient to high evidence of depth, and $11 \%$ reflected sufficient to high evidence of growth mindset. See Table 4 for percentage of responses reflecting various levels of accuracy, depth, and growth mindset.

Table 4.

Participant Responses Reflecting Accuracy, Depth, and Growth Mindset

\begin{tabular}{lccc}
\hline Response & Accuracy & Depth & Growth Mindset \\
\hline No evidence & $45 \%$ & $45 \%$ & $40 \%$ \\
Little evidence & $30 \%$ & $24 \%$ & $20 \%$ \\
Some evidence & $14 \%$ & $23 \%$ & $29 \%$ \\
Sufficient evidence & $8 \%$ & $6 \%$ & $9 \%$ \\
High evidence & $3 \%$ & $2 \%$ & $2 \%$ \\
\hline
\end{tabular}

\section{Discussion}

The goal of this study was to explore the perceptions and knowledge of pre-service special educators about the reading needs and achievement of children with DS. More than $80 \%$ of the pre-service teachers in this study believed that children with DS could benefit from reading instruction, and that this instruction would improve their cognitive and language skills. This finding is aligned with prior research on the potential and achievement of children with DS in reading (Buckley, 1995; Byrne et al., 1995; Byrne et al., 2002; Cologon et al., 2011; Lemons \& Fuchs, 2010; Lemons et al., 2012; Ricci, 2011a, 2011b). Furthermore, this is positive news for parents of children with DS, who have long advocated for educators to recognize the reading potential of their children (Fidler et al., 2002; Fidler et al., 2003).

In responses to how they would approach reading for children with DS, the preservice special educators in this study discussed the content and pedagogy of reading instruction, along with connections to the home. Responses that emphasized the development of the key readings skills of phonemic awareness, sight words, decoding skills, vocabulary, and comprehension for these students were indeed promising, as were the pedagogical recommendations including explicit, hands-on approaches; visuals; guided reading; and matching intervention to students' needs based on assessment data (Allor et al., 2010; Allor et al., 2014; Cologon, 2013; Lemons et al., 2012; Lemons et al., 2017; Næss et al., 2012). The pre-service special educators also discussed the importance of home-school connections in developing these students' reading skills, such as establishing literature-rich environments and encouraging parents to read aloud and model a love of reading for their children with DS. These responses about the content and pedagogy of reading, as well as parental involvement, were appropriate for developing the reading skills of children with DS.

Yet, of these pre-service special educators, only 53\% reported feeling competent about teaching reading to children with DS on the survey, and $42 \%$ either stated that they 
were unsure or did not have a response for how they would approach reading instruction for these students. In the analysis of their responses, we found that nearly half showed little to some evidence of accuracy, depth, and growth mindset in teaching children with DS to read, with only $11 \%$ or less showing sufficient to high evidence in these areas. This can be alarming given that parents of children with DS are looking for teachers as partners in developing the literacy skills of their children, with many having started this work in their homes and wanting teachers to further their children's potential (Al Otaiba et al., 2009; Ricci, 2011a; Ricci \& Osipova, 2012).

Perhaps these findings were due to the fact that participants were still pre-service special educators not having yet completed the reading course in their teaching credential programs or still needing to cement for themselves how teachers should differentiate instruction for all students. However, teacher educators should pay particular attention to honing the skills of pre-service teachers in teaching reading, particularly to students with specific disabilities such as DS, in alignment with a data-based individualization approach to reading (Lemons, Kearns, \& Davidson, 2014). Also, in this study, those preservice special educators who reported prior experience with children with DS scored higher on the survey, indicating the importance of providing fieldwork experiences in working with children with DS (and indeed other types of disabilities) that will help these pre-service special educators be more receptive to and competent in teaching reading to this population. Having more direct fieldwork experiences with students with a variety of developmental disabilities might increase teachers' effectiveness in differentiating instruction to meet the needs of all students.

The limitations of this study should be considered. First, the research was based on self-reported perceptions of pre-service special educators, rather than on an evaluation of their actual skills in teaching children with DS. The present study also did not ask the pre-service teachers about their confidence in teaching any child to read, or any child with a disability. Further exploration of the pre-service teachers' perceptions of teaching reading to all children, children who are typically developing, and children with other developmental disabilities would shed more light on these findings. The sample size of this study could have been larger to extend the generalizability of the findings. Furthermore, following up with the pre-service educators after their completion of their reading course and/or teaching credentials could have yielded further knowledge about their competency in teaching reading to children with DS.

Nevertheless, as one of few studies examining the perceptions and knowledge of pre-service special educators in teaching reading to this population, this study contributes to the knowledge base, further highlighting the importance of training pre-service teachers in both reading instruction and disability-specific content. Only with attention to developing the skills of children with DS can educators realize these students' full potential for reading and adhere to the priority of literacy for all.

\section{References}

Allor, J. H., Mathes, P. G., Roberts, J. K., Cheatham, J. P., \& Al Otaiba, S. (2014). Is scientifically based reading instruction effective for students with below-average IQs? Exceptional Children, 80(3), 287-306. 
Allor, J. H., Mathes, P. G., Roberts, J. K., Cheatham, J. P., \& Champlin, T. M. (2010). Comprehensive reading instruction for students with intellectual disabilities: Findings from the first three years of a longitudinal study. Psychology in the Schools, 47(5), 445-466.

Al Otaiba, S., Lewis, S., \& Whalon, K. (2009) Home literacy environments of young children with Down syndrome: Findings from a web-based survey. Remedial and Special Education, 30, 96-107.

American Federation of Teachers. (2008). Improved early reading instruction and intervention. Washington, DC: Author.

Beeghly, M., \& Cicchetti, D. (1997). Talking about self and other: Emergence of an internal state lexicon in young children with Down syndrome. Development and Psychopathology, 9(4), 729-748.

Brantlinger, E., Jimenez, R., Klingner, J., Pugach, M., \& and Richardson, V. (2005). Qualitative studies in special education. Exceptional Children, 71, 195-207.

Buckley, S. (1995). Teaching children with Down syndrome to read and write. In L. Nadel \& D. Rosenthal (Eds.), Down syndrome: Living and learning in the community (pp. 158-169). New York, NY: Wiley-Liss.

Buckley, S. J. (2001). Reading and writing for individuals with Down syndrome-An overview. Down Syndrome Issues and Information. Down Syndrome Education International.

Buckley, S., Bird G., \& Byrne A. (1996) The practical and theoretical significance of teaching literacy skills to children with Down's. In J. A. Rondal, J. Perera, L. Nadel, \& A. Comblain (Eds.), Down's syndrome: Psychological, psychobiological, and socio-educational perspectives (pp. 119-128). London, UK: Whurr.

Buckley, S. J., \& Johnson-Glenberg, M.J. (2008). Increasing literacy learning for individuals with Down syndrome and fragile X syndrome. In J. E. Roberts, R. S. Chapman, \& S. F. Warren (Eds.), Communication and language intervention series: Speech and language development and intervention in Down syndrome and fragile X syndrome (pp. 233-254). Baltimore, MD: Brookes.

Buckley, S., \& Sacks B. I. (1987). The adolescent with Down's syndrome-Life for the Teenager and for the family. Portsmouth, UK: Portsmouth Polytechnic.

Burgoyne, K., Duff, F. J., Clarke, P. J., Buckley, S. J., Snowling, M. J., \& Hulme, C. (2012). Efficacy of a reading and language intervention for children with Down syndrome: A randomised controlled trial. Journal of Child Psychology and Psychiatry. doi:10.1111/j.14697610.2012.02557.x

Byrne, A., Buckley, S., MacDonald, J., \& Bird, G. (1995) Investigating the literacy, language, and memory skills of children with Down's syndrome. Down's Syndrome: Research and Practice, 3, 53-58.

Byrne, A., MacDonald, J., \& Buckley, S. (2002) Reading, language, and memory skills: A comparative longitudinal study of children with Down syndrome and their mainstream peers. British Journal of Educational Psychology, 72, 513-529.

Chapman, R. S., \& Hesketh, L. J. (2000). Behavioral phenotype of individuals with Down syndrome. Mental Retardation and Developmental Disabilities, 6, 84-95.

Cologon, C. (2013). Debunking myths: Reading development in children with Down syndrome. Australian Journal of Teacher Education, 38(3), 130-151.

Cologon, K., Cupples, L., \& Wyver, S. (2011). Effects of targeted reading instruction on phonological awareness and phonic decoding in children with Down syndrome. American Journal on Intellectual and Developmental Disabilities, 116, 111-129. 
Colozzo, P., McKeil, L., Petersen, J. M., \& Szabo, A. (2016). An early literacy program for young children with Down syndrome: Changes observed over one year. Journal of Policy and Practice in Intellectual Disabilities, 13, 102-110.

Common Core State Standards Initiative. (2014). Common Core Standards Initiative: Preparing America's students for college and career [Website]. Retrieved from $\mathrm{http}: / /$ www.corestandards.org

Connor, C.M., Alberto, P. A., Compton, D. L., O'Connor, R. E. (2014). Improving reading outcomes for students with or at risk for reading disabilities: A synthesis of the contributions from the Institute of Education Sciences Research Centers (NCSER 2014-3000). Washington, DC: National Center for Special Education Research, Institute of Education Sciences, U.S. Department of Education.

Daunhauer, L. A., \& Fidler, D. J. (2011). The Down syndrome behavioral phenotype: Implications for practice and research in occupational therapy. Occupational Therapy In Health Care, 25(1), 7-25.

Fidler, D. J., Hodapp, R. M., \& Dykens, E. M. (2002). Behavioral phenotypes and special education: Parent report of educational issues for children with Down syndrome, Prader-Willi syndrome, and Williams syndrome. The Journal of Special Education, 36, 80-88.

Fidler, D. J., Lawson, J. E., \& Hodapp, R. M. (2003). What do parents want?: An analysis Of education-related comments made by parents of children with different genetic syndromes. Journal of Intellectual and Developmental Disability, 28(2), 196- 204.

Fitzgerald, J., Roberts, J., Pierce, P., \& Schuele, M. (1995). Evaluation of home literacy environment: An illustration with preschool children with Down syndrome. Reading \& Writing Quarterly: Overcoming Learning Difficulties, 11, 311-334.

Fowler A. (1990). Language abilities in children with Down syndrome: Evidence for a specific syntactic delay. In D. Cicchetti \& M. Beeghly (Eds.), Children with Down syndrome: A developmental perspective (pp. 302-328). Cambridge, UK: Cambridge University Press.

Frenkel, S., \& Bourdin, B. (2009). Verbal, visual, and spatio-sequential short-term memory: Assessment of the storage capacities of children and teenagers with Down's syndrome. Journal of Intellectual Disability Research, 53(2), 152-160.

Glaser, B., \& Strauss, A. (1967). The discovery of grounded theory: Strategies of qualitative research. London, UK: Wiedenfeld and Nicholson.

Hodapp R. M., Evans D., \& Gray F. L. (1999). Intellectual development in children with Down syndrome. In J. A. Rondal, J. Perera, \& L. Nadel (Eds.), Down's syndrome: A review of current knowledge (pp. 124-132). London, UK: Whurr.

Hodapp, R. M., \& Ricci, L. A. (2002). Behavioral phenotypes and educational practice: The unrealized connection. In G. O’Brien \& O. Udwin (Eds.), Behavioral phenotypes in clinical practice. London, UK: Mac Keith Press.

Kumin, L. (1994). Intelligibility of speech in children with Down syndrome in natural settings: Parents' perspective. Perceptual and Motor Skills, 78, 307-313.

Laws, G., Buckley, S. J., Bird, G., MacDonald, J., \& Broadley, I. (1995). The influence of reading instruction on language and memory development in children with Down syndrome. Down Syndrome Research and Practice, 3(2), 59-64.

Leddy, M. (1999). The biological bases of speech in people with Down syndrome. In J. F. Miller, M. Leddy, \& L. A. Leavitt (Eds.), Improving the communication of people with Down syndrome (pp. 61-80). Baltimore, MD: Paul H. Brookes. 
Lemons, C. J., \& Fuchs, D. (2010). Phonological awareness of children with Down syndrome: Its role in learning to read and the effectiveness of related interventions. Research in Developmental Disabilities, 31, 316-330.

Lemons, C. J., Kearns, D. M., \& Davidson, K. A. (2014). Data-based individualization in reading. Teaching Exceptional Children, 46(4), 20-29.

Lemons, C. J., King, S. A., Davidson, K. A., Puranik, C. S., Al Otaiba, S., \& Fidler, D. J. (2017). Personalized reading intervention for children with Down syndrome. Journal of School Psychology, 66, 67-84. doi:10.1016/j.jsp.2017.07.006

Lemons, C. J., Mrachko, A. A., Kostewicz, D. E., \& Paterra, M. F. (2012). Effectiveness of decoding and phonological awareness interventions for children with Down syndrome. Exceptional Children, 79(1), 67-90.

Næss, K. B., Melby-Lervåg, M., Hulme, C., \& Lyster, S. H. (2012). Reading skills in children with Down syndrome: A meta-analytic review. Research In Developmental Disabilities: A Multidisciplinary Journal, 33(2), 737-747.

National Reading Panel. (2000). Teaching children to read: An evidence-based assessment of the scientific research literature on reading and its implications for reading instruction. Washington, DC: National Institute of Child Health and Human Development.

No Child Left Behind Act of 2001, P.L. No. 107-110, 115 Stat.1425, 20 U.S.C. $\S \S 6301$ et seq.

Ricci, L. A. (2011a). Exploration of reading interest and emergent literacy skills of children with Down syndrome. International Journal of Special Education, 26(3), 1-11.

Ricci, L. (2011b). Home literacy environments, interest in reading, and emergent literacy skills of children with Down syndrome versus typical children. Journal of Intellectual Disability Research, 55(6), 596-609.

Ricci, L. A., \& Osipova, A. (2012). Visions for literacy: Parents' aspirations for reading in children with Down syndrome. British Journal of Special Education, 39(3), 123-129.

Sulzby, E., \& Teale, W. (1991). Emergent literacy. In R. Barr, M. Kamil, P. Mosenthal, \& P. D. Pearson (Eds.), Handbook of reading research (Vol. II, pp. 727-757). New York, NY: Longman.

van Bysterveldt, A., \& Gillon, G. (2014). A descriptive study examining phonological awareness and literacy development in children with Down syndrome. Folia Phoniatrica et Logopaedica, $66(1-2), 48-57$.

Vicari S., Marotta L., \& Carlesimo G. A. (2004). Verbal short-term memory in Down's syndrome: An articulatory loop deficit? Journal of Intellectual Disability Research, 48, 80-92.

Whitehurst, G. J., \& Lonigan, C. J. (1998). Child development and emergent literacy. Child Development, 69(3), 848-872.

\section{Authors' Note}

Correspondence concerning this article should be addressed to Leila Ricci, California State University, Los Angeles, 5151 State University Drive, Los Angeles, CA, 90032, U.S.A. Email: Lricci@calstatela.edu 